\title{
Cell recovery during segmental intestinal perfusion in healthy subjects and patients with Crohn's disease
}

\author{
Ö Ahrenstedt, F Knutson, L Knutson, M Krog, O Sjöberg, R Hällgren
}

\begin{abstract}
The recovery of cells arising from small intestinal mucosa alone was studied during continuous perfusion of a closed segment of jejunum. The perfusion technique minimised the contamination of the perfused segment with, for example, proteolytic enzymes from pancreas, allowing recovery of viable cells. The use of hyaluronidase in the perfusion fluid increased the recovery of cells fivefold, the median recovery being $8 \times 10^{6}$ cells. The cells were analysed with monoclonal antibodies and flow cytometry. Nearly all cells (98-99\%) recovered during perfusion of healthy control subjects and patients with Crohn's disease were epithelial cells. The jejunal cells expressed HLA-DR in similar proportions around $30 \%$ - in patients and control subjects. The ratio between $\mathrm{CD}^{+}$and $\mathrm{CD8}^{+}$lymphocytes was similar (0.2) in control subjects and patients with inactive Crohn's disease but decreased $(0.03)$ in patients with active Crohn's disease in the ileum.
\end{abstract}

Characterisation and functional studies of cells in the intestinal mucosa have been based on biopsy specimens. Immunohistochemical staining of biopsy sections have given valuable information on the cellular events in health and disease. Some of the surface markers, however, may disappear with the use of the immunoperoxidase technique on frozen sections of the intestine.' Isolated cell populations from gut specimens have been used for various functional studies. In inflammatory bowel disease, mitogen-stimulated proliferation of isolated lymphocytes has been found to be both increased ${ }^{23}$ and decreased, ${ }^{45}$ possibly owing to the isolation procedure. ${ }^{6}$ Thus the methods used today are limited by problems of trauma during collection of tissue specimens and time consuming cell isolation procedures.

One aim of this study was to elucidate cell recovery during jejunal perfusion of healthy control subjects and patients with Crohn's disease. A further aim was to characterise jejunal cells recovered during perfusion: the HLA-DR expression of epithelial cells and lymphocyte reactivity to various monoclonal antibodies. For this purpose we used a flow cytometry technique.

\section{Methods}

PATIENTS AND CONTROLS

Fourteen patients with Crohn's disease were examined (10 women, four men; mean age 40 years, range 21 to 62 years). Four patients had had colectomies or ileostomies and had no sign of recurrence; the Crohn's disease activity index was $<150 .^{8}$ Ten patients had had ileocaecal resections. Five of these had no radiological signs of recurrence and a Crohn's disease activity index of $<150$; five had radiological signs of Crohn's disease in the terminal ileum and a mean index of 230 (range 170 to 280). None of the patients, apart from one taking metronidazole, had received any medical treatment for Crohn's disease as steroids, antibiotics, or non-steroidal anti-inflammatory drugs within the previous three months. Nine healthy volunteers (two women, seven men; mean age 30 years) were given a jejunal perfusion. An ileal perfusion was performed on four patients with Crohn's disease who had had a colectomy or an ileostomy (two women, two men; mean age 40 years, range 25 to 54 years). Three men (mean age 42 years, range 25 to 53 years) with ulcerative colitis, who had had a colectomy or an ileostomy served as controls for the ileal perfusion. Patients and control subjects gave informed consent to the study, which was approved by the Ethic Committee of the Medical Faculty, Uppsala University.

\section{SEGMENTAL INTESTINAL PERFUSION}

Segmental intestinal perfusion was achieved by a small diameter tube (LOC-I-GUT, Pharmacia, Uppsala, Sweden) containing six channels and two balloons for isolation of a $10 \mathrm{~cm}$ segment. ${ }^{9}$ The balloons were inflated when the tube was in place in the proximal jejunum or by retrograde intubation of the ileum, on average $40 \mathrm{~cm}$, proximal to the stoma. The segment was rinsed with $120 \mathrm{ml} 154 \mathrm{mM} \mathrm{NaCl}$ solution, at $37^{\circ} \mathrm{C}$ over 30 minutes. After that recovery of cells started during continuous perfusion of the segment at $3 \mathrm{ml}$ per minute with a solution $\left(37^{\circ} \mathrm{C}\right)$ containing $10 \mathrm{mM}$ glucose, $5.4 \mathrm{mM} \mathrm{KCl}$, $120 \mathrm{mM} \mathrm{NaCl}, 2 \mathrm{mM} \mathrm{Na} \mathrm{HPO}_{4}, 35 \mathrm{mM}$ mannitol, osmolality $290 \mathrm{mOsm} / \mathrm{l} ; 1 \mathrm{~g} / \mathrm{l}$ of ${ }^{1+} \mathrm{C}$ labelled polyethylene glycol $\left({ }^{1+} \mathrm{C}-\mathrm{PEG}, \mathrm{MW} 4000\right.$ daltons, $2 \cdot 5 \mu \mathrm{Ci} / 1$, Amersham, Buckinghamshire, UK) was added to the perfusion solution as a volume marker. ${ }^{10}$ Hyaluronidase, $200 \mathrm{IU} / 1$ (Hyalas, Ferrosan, Sweden) was added to increase the release of cells. Ten $\mathrm{ml}$ of aprotinin, $10000 \mathrm{KIU} / \mathrm{l}$ (Bayer AG, Leverkusen, FRG) was added to every litre of perfusion solution to inhibit proteolytic activity that might have contaminated the perfusate. Another $0.6 \mathrm{ml}$ of aprotinin was added to every $60 \mathrm{ml}$ of effluent. The duration of the perfusion was usually 180 minutes. To prevent leakage at the proximal balloon, phenol red solution $(50 \mathrm{mg} / \mathrm{l}$ in $154 \mathrm{mM}$ $\mathrm{NaCl}$ ) was infused into the stomach through the sump line of the Salem-sump tube (jejunum), or in a proximal channel (ileum), at a rate of 
Monoclonal antibodies used for characterisation of cells

\begin{tabular}{|c|c|c|}
\hline Antibody & $\begin{array}{l}\text { Antigen } \\
\text { (cluster } \\
\text { designation) }\end{array}$ & Predominant reactivity \\
\hline Anti-Leuco & CD45 & Leucocytes \\
\hline Anti-Leu-M1 & CD15 & Monocytes/granulocytes \\
\hline Anti-Leu-M3 & $\mathrm{CDl} 4$ & Monocytes/macrophages \\
\hline Anti-Leu-2 & CD8 & T cytotoxic/suppressor cells \\
\hline Anti-Leu-3 & $\mathrm{CD} 4$ & T helper/inducer cells \\
\hline Anti-Leu-4 & $\mathrm{CD} 3$ & T cells (mitogenic) \\
\hline Anti-Leu-7 & & $\mathrm{T}$ cells and NK cell subsets \\
\hline Anti-Leu-11 & CD16 & $\begin{array}{l}\text { Fc IgG receptor on NK cells } \\
\text { and neutrophils }\end{array}$ \\
\hline Anti-Leu-12 & CD19 & B cells \\
\hline Anti-Leu-15 & CD11 & $\begin{array}{l}\text { T suppressor cells, NK cells, } \\
\text { monocytes, and granulocytes }\end{array}$ \\
\hline Anti-Leu-18 & CD45R & $\begin{array}{l}\text { T suppressor/inducer subset, } \\
\text { NK cells, B cells }\end{array}$ \\
\hline Anti-HLA-DR & - & $\begin{array}{l}\text { B cells, monocytes, } \\
\text { macrophages, activated T } \\
\text { cells, and epithelial cells }\end{array}$ \\
\hline
\end{tabular}

$\mathrm{NK}=$ natural killer.

$1 \mathrm{ml} / \mathrm{min}$ and analysed in the effluent from the intestinal segment. The effluent was continuously drained by gravity suction and collected on ice every 20 minutes. Each collected fraction was immediately centrifuged. The cell pellets were resuspended and pooled in a culture medium (RPM 1640, Flow industries, UK) with the addition of HPG (Hepes-penicillin/streptomycin-glutamine) and $10 \%$ fetal calf serum. The cell suspension was centrifuged and resuspended in phosphate buffered saline before cell counting and analysis, which was performed within four hours of perfusion.

\section{ANALYTICAL MEASUREMENTS}

${ }^{14} \mathrm{C}$-PEG was determined by liquid scintillation counting of $1 \mathrm{ml}$ aliquots (LKB Rackbeta II, liquid scintillation counter, Wallac Oy, Turku, Finland) in duplicate for 15 minutes. " Phenol red was measured spectrophotometrically at $520 \mathrm{~nm}$ (Hitachi Ltd, Tokyo, Japan) after alkalinisation (pH 11) with $\mathrm{Na}_{3} \mathrm{PO}_{4}$ buffer. ${ }^{12}$ Measurements were performed on cells obtained over the whole perfusion time.

\section{ANTIBODIES}

The monoclonal antibodies (Becton Dickinson, Mt View, California, USA) are listed in the Table. They were directly conjugated to fluorescein isothiocyanate or phycoerythrin. Some were also used as unconjugated antibodies and combined with a $\mathrm{Fab}_{2}$ rabbit anti-mouse (RAM) antibody conjugated with phycoerythrin (Serotec Ltd, Oxford, UK).

\section{STAINING OF CELLS}

For direct immunofluorescence staining, $0.5 \times 10^{6}$ cells were incubated with $25 \mu \mathrm{l}$ fluorescein isothiocyanate or phycoerythrin conjugated antibodies, or both, for 10 minutes at room temperature. The cells were then washed in phosphate buffered saline (PBS), suspended in $300 \mu \mathrm{l} \mathrm{PBS}$ with $0 \cdot 1 \%$ sodium azide and $2 \%$ fetal calf serum, and fixed in $300 \mu \mathrm{l}$ PBS with $1 \%$ paraformaldehyde and $1 \%$ fetal calf serum. For indirect immunofluorescence staining, cells were incubated at room temperature with $25 \mu$ of unconjugated primary monoclonal antibody for
10 minutes. The cells were washed as above followed by incubation with $25 \mu \mathrm{l}$ of RAMphycoerythrin antibody. After washing, free binding sites on the RAM antibodies were blocked by a 5 minute incubation with normal mouse serum (diluted 1:100). After washing, the fluorescein isothiocyanate conjugated monoclonal antibody was added for 10 minutes, with a final wash before fixation as above.

\section{FLOW CYTOMETRY}

Flow cytometric analyses were performed with a FACStar (Becton Dickinson), equipped with a 5W Argon ion laser run at $488 \mathrm{~nm}$ for an output of $200 \mathrm{~mW}$. Green fluorescence (fluorescein isothiocyanate) was collected through a 530 per $30 \mathrm{~nm}$ bandpass filter, and red (phycoerythrin) through a 585 per $42 \mathrm{~nm}$ bandpass filter. A $560 \mathrm{~nm}$ dichromic mirror was used to split red and green signals. All these features are part of the standard configuration on the FACStar. The forward scatter, corresponding to granularity, and the two fluorescence signals were collected in logarithmic mode and evaluated with Consort 30 software on a Hewlett-Packard 9000 series model 310 computer: $5 \times 10^{3}$ cells were analysed.

\section{Results}

\section{RECOVERY OF CELLS}

The method of perfusing a closed jejunal segment was successful, with a contamination of less than $5 \%$ according to phenol red, and the ${ }^{1+} \mathrm{C}$ PEG recovery was more than $80 \%$ over the whole study period. The perfusion of distal ileum was technically more complicated owing to the viscosity of the intestinal secretion, which clogged the drainage channel. Only the results from the best periods of ileal perfusion, usually at the start of the perfusion, are presented. The contamination of phenol red was $23 \%$ and the mean recovery of ${ }^{14} \mathrm{C}-\mathrm{PEG} 75 \%$ during these periods.

Cell recovery during jejunal perfusion increased on average five times with the addition of hyaluronidase to the perfusion fluid. Cell recovery was therefore studied with enzyme present. The median recovery of cells was $8 \times 10^{6}$

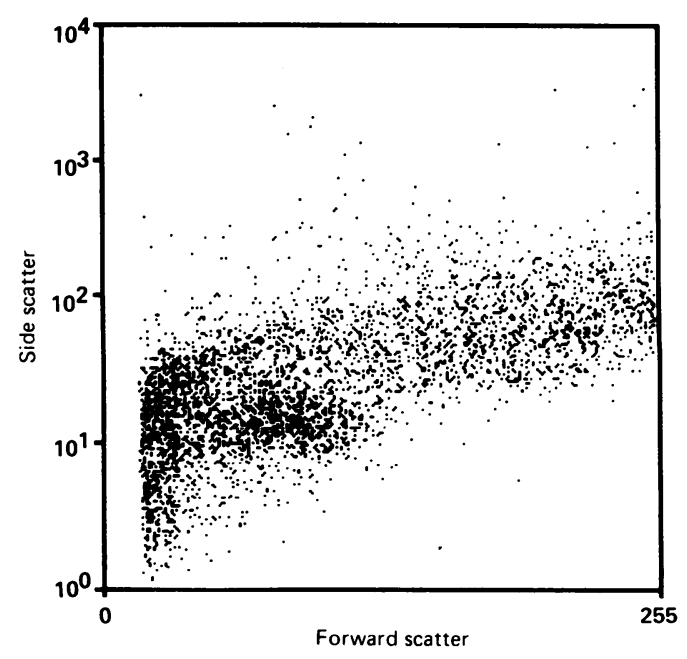

Figure 1: Scatter pattern of cells obtained with intestinal perfusion. 


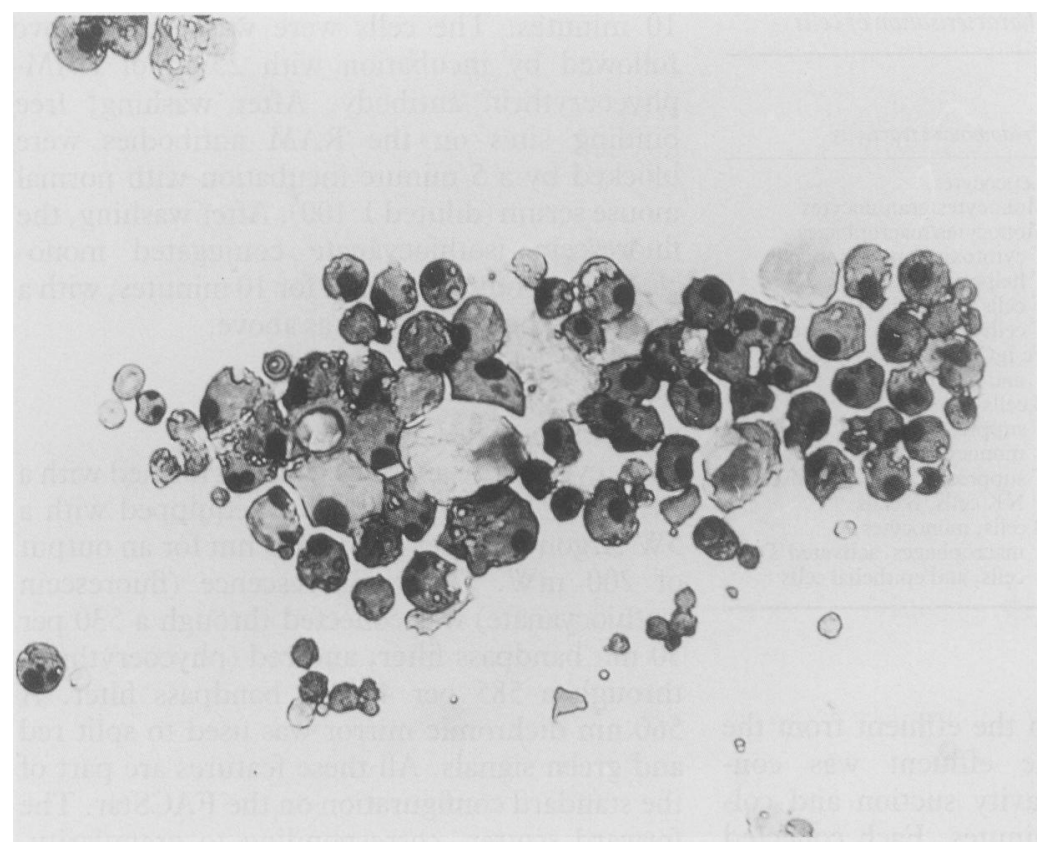

Figure 2: A cytocentrifuge preparation of cells recovered during intestinal perfusion of a healthy volunteer. The cell preparation is dominated by epithelial cells. (May-Grünwald-Giemsa staining).
CELLS EXPRESSING HLA-DR

Cells recovered during jejunal lavage expressed HLA-DR in similar proportions in control subjects (mean (SEM) 29.6 (7.7)\%), patients with inactive disease $(25.9(19.4) \%)$, and patients with active Crohn's disease $(30 \cdot 6(5 \cdot 4) \%)$.

\section{Discussion}

This study has shown that large numbers of viable epithelial cells are recovered from healthy control subjects and patients with Crohn's disease during perfusion of a jejunal segment provided that hyaluronidase is present in the perfusion fluid. This enzyme is specific for the glycosaminoglycan hyaluronan (hyaluronic acid or hyaluronate by older nomenclature). Large amounts of hyaluronan are found in jejunal lumen, ${ }^{91314}$ indicating considerable local synthesis of this connective tissue component, for which a role in intercellular adhesion has been suggested. ${ }^{15}$ Recently we have visualised hyaluronan in the loose connective tissue of the villi. ${ }^{16}$ Furthermore, hyaluronan accumulates in the subepithelial structure. This histochemical localisation of hyaluronan together with our findings of increased cell recovery in the presence of hyaluronidase suggest that hyaluronan is involved in the epithelial cell attachment to lamina propria. The site from which exfoliated epithelial cells are derived during continuous jejunal perfusion in humans has not been identified. The recovered cells, however, are likely to be villous tip cells, since intestinal epithelial cells divide in the fundus of the villi and move continuously towards the tip of the villi where they are shed. In experimental studies the chelating agent ethylenediaminetetra-acetate has been used in perfusion fluid to increase the recovery of epithelial cells in view of the role of calcium ions in cell adhesion. ${ }^{17}$ But the epithelial cells recovered were trapped in mucus and therefore not suitable for analysis by flow cytometry. The cells recovered during jejunal perfusion in the presence of hyaluronidase evidently escaped from the mucus, while the perfusion of distal ileum in patients with stoma often was complicated by the high viscosity of the intestinal secretion.

Most of the cells recovered during jejunal Jejunal recovery of CD $45^{+}$leucocytes in healthy control subjects was $0 \cdot 8(0.3) \%$ (mean (SEM)) and in patients with Crohn's disease $1 \cdot 1(0 \cdot 3) \%$. The recovery of these cells was related to disease activity; patients with active disease had a twofold increase of $\mathrm{CD} 5^{+}$cells $(1 \cdot 4(0 \cdot 4) \%$, while patients with inactive disease had a similar recovery to the control subjects $(0 \cdot 9(0 \cdot 3) \%)$.

The lymphocytes were grouped according to their reactivity with CD4 and CD8. The proportion of $\mathrm{CD}^{+}$cells was decreased in active Crohn's disease, giving a low $\mathrm{CD}^{+} / \mathrm{CD}^{+}$ratio $(0.03)$ compared with the ratio in healthy controls $(0 \cdot 2)$. The ratio of lymphocytes recovered during ileal lavage of patients with stoma and inactive Crohn's disease or ulcerative colitis was 0.5 and 0.3 , respectively. A few cells positive for CD3, Leu-7, CD14, CD15, and CD19 were found in patients and control subjects (data not shown). No recovered cells expressed the antigens CD11, CD16, and CD45R. lavage were epithelial cells, as in previous experimental studies. ${ }^{17-19}$ About a third of the epithelial cells from healthy control subjects expressed HLA-DR. Previous immunohistochemical studies of jejunal biopsy specimens have also claimed the presence of activated epithelial cells in healthy specimens. ${ }^{20} \mathrm{~A}$ similar proportion of jejunal epithelial cells staining with anti-HLADR was seen in our patients with Crohn's disease affecting the distal ileum.

Attempts to collect cells from small intestinal washings have been made in experimental animals. The methods used have included simple aspiration of intestinal fluid and the conventional small intestinal perfusion technique. ${ }^{1721}$ Specimens obtained by these methods, however, contained cells that were completely disrupted and converted to an amorphous mass, probably owing to the high enzyme content of the intestinal fluid in the lumen. This problem 
was partly overcome in experimental studies by occlusion of the small intestine and rapid washing of the small intestine. ${ }^{17} \mathrm{~A}$ few washings of small intestine in humans have been performed by using a triple lumen tube, ${ }^{19}$ but the recovery of small intestinal epithelial cells was unsatisfactory because they were damaged and impossible to identify by light microscopy. The success of the present six lumen catheter technique with two occluding balloons is based on the principle that material from the stomach, biliary tract, and pancreas is prevented from entering the perfused segment. Furthermore, the addition of protease inhibitors to the perfusion fluid prevents a cell damaging effect owing to a possible contamination of the perfusate with minute amounts of proteolytic enzymes.

The number of lymphocytes recovered during jejunal perfusion of healthy control subjects was about $8 \times 10^{4}$ cells - that is, about $1 \%$ of the total cell recovery. The jejunal recovery of lymphocytes was similar in patients with inactive Crohn's disease but was on average $2 \%$ in patients with active disease in the distal ileum. The paucity of recovered lymphocytes was surprising but in accordance with previous perfusion studies. ${ }^{18}$ It seems that the recovery of lymphocytes is not representative of the physiological populations covering the villi but may present cells derived from lymphoid aggregates and Peyer's patches. Therefore, the phenotypic characterisation of recovered cells must be interpreted with caution. The ratio between $\mathrm{CD} 4^{+}$ and $\mathrm{CD}^{+}$cells (helper/inducer cells and cytotoxic/suppressor cells, respectively) was similar in control subjects and patients with inactive Crohn's disease but apparently lower in patients with active Crohn's disease owing to a relative decrease of $\mathrm{CD}^{+}$cells. Interestingly, this relation between $\mathrm{CD}^{+}$and $\mathrm{CD}^{+}$cells has also been reported in immunohistochemical studies of biopsy specimens from Crohn's lesions. ${ }^{22}$ The altered cellular response in an area of the intestine not apparently affected by the disease may reflect a more generalised nature of the disease as previously suggested by an increased secretion of complement components and histamine in nonaffected areas of the intestine in patients with Crohn's disease. ${ }^{2324}$ The few lymphocytes recovered did not allow conclusive flow cytometry analyses with other monoclonal antibodies with reactivity for less frequent appearing antigen structures on lymphocytes. Nor did flow cytometry analyses using monoclonal antibodies directed against monocytes/macrophages give reliable data owing to the small number of such cells in the perfusion fluid. The $\mathrm{CD}^{+} / \mathrm{CD}^{+}$ ratio for lymphocytes recovered during ileal perfusion in patients with ulcerative colitis and active Crohn's disease with a stoma was similar to the corresponding jejunal ratio for healthy control subjects.

This study has shown a new way to obtain viable epithelial cells from the small intestine in vivo. The cell recovery obtained by jejunal lavage minimises the time from harvest to analysis of cells. The observation that epithelial cells appear in more than $98 \%$ of all cells recovered is of potential value for characterisation of epithelial cell function in a primary highly purified epithelial cell preparation. The use of the technique for the characterisation of lymphocytes seems more uncertain because of the limited recovery of such cells.

This work was supported by grants from Swedish Medical Research Council, the Tore Nilson Foundation, the Lennanders Foundation, and Pharmacia, Sweden.

1 Fiocchi C, Tubbs RR, Youngman KR. Human intestinal mucosal mononuclear cells exhibit lymphokine-activated killer cell activity. Gastroenterology 1985; 88: 625-37.

2 Fiocchi C, Battisto JR, Farmer RG. Gut mucosal lymphocytes in inflammatory bowel disease; isolation and preliminary functional characterization. Dig Dis Sci 1979; 24: 705-17.

3 Goodacre RL, Bienenstock J. Reduced suppressor cell activity in intestinal lymphocytes from patients with Crohn's disease. Gastroenterology 1984; 86: A1068.

4 MacDermott RP, Bragdon MJ, Jenkins KM, Franklin GO, Shedlofsky S, Kodner IJ. Human intestinal mononuclear cells. Demonstration of a naturally occurring subclass of $\mathrm{T}$ cells which respond in the allogeneic mixed leucocyte reaction but do not effect cell mediated lympholysis. Gastroenterology 1981; 80: 748-57.

5 Clancy R. Isolation and kinetic characteristics of mucosal lymphocytes in Crohn's disease. Gastroenterology 1976; 70: 177-80.

6 Bland PW, Richens ER, Britton DC, Lloyd JV. Isolation and purification of human large bowel mucosal lymphoid cells: effect of separation technique on functional characteristics. Gut 1979; 20: 1037-46.

7 Ferguson A. Why study T cell subsets in Crohn's disease? Gut 1983; 24: 687-91.

8 Best WR, Becktel JM, Singleton JW, Kern F Jr. Development of a Crohn's disease activity index. Gastroenterology 1976, 79: $439-44$.

9 Knutson L, Odlind B, Hällgren R. A new technique for segmental jejunal perfusion in man. Am $\mathcal{F}$ Gastroenterol 1989 ; 84: 1278-84

10 Hydén $S$. The recovery of polyethylene glycol after passage through the digestive tract. Annals of the Royal Agricultural College 1956; 22: 411-24.

11 Stern AI, Hogan DL, Isenburg JI. A new method for quantitation of ion fluxes across the in vivo human gastric mucosa. Gastroenterology 1984; 86: 60-70.

12 George JD. New clinical method for measuring the rate of gastric emptying: the double sampling test meal. Gut 1968; 9: $237-42$.

13 Colombel JF, Hällgren R, Engström-Laurent A, Rambaud JC. Hyaluronic acid and type III procollagen peptide in
jejunal perfusion fluid as markers of connective tissue jejunal perfusion fluid as markers of
turnover. Gastroenterology 1989; $96: 68-73$.

14 Lavö B, Knutson L, Lööf L, Odlind B, Hällgren R. Signs of increased leakage from the jejunal mucosa during gliadin challenge of patients with celiac disease. Am $\mathcal{F}$ Gastroentero 1989; 87: 655-60.

15 Tammi R, Ripellino JA, Margolis RU, Tammi M. Localization of epidermal hyaluronic acid using the hyaluronate binding region of cartilage proteoglycan as a specific probe. f Invest Dermatol 1988; 90: 412-4.

16 Gerdin B, Hällgren R. Localisation of hyaluronan in the human intestinal wall. Gut (in press).

17 Clarke RM. A new method of measuring the rate of shedding of epithelial cells from the intestinal villus of the rat. Gut of epithelial cells

18 Pink IJ, Croft DN, Creamer B. Cell loss from intestinal mucosa: a morphological study. Gut 1970; 11: 217-22.

19 Da Costa LR, Croft DN, Creamer B. Protein loss and cell los from the small-intestinal mucosa. Gut 1971; 12: 179-83.

20 Chiba $M$, Iizuka $M$, Masamune $O$. Ubiquitous expression of HLA-DR antigens on human small intestinal epithelium Gastroenterol fon 1988; 23: 109-16.

21 Cooper H, Levtan R, Fordtran JS, Ingelfinger FJ. A method for studying absorption of water and solute from the human for studying absorption of water and solute from

22 Fiocchi C, Youngman KR, Farmer RG. Immunoregulatory function of human intestinal mucosa lymphoid cells: evidence for enhanced suppressor cell activity in inflammatory bowel disease. Gut 1983; 24: 692-701.

23 Ahrenstedt Ö, Knutson L, Nilsson B, Nilsson-Ekdahl $K$, Odlind B, Hällgren R. Enhanced local production of complement components in the small intestine in Crohn's disease. N Engl F Med 1990; 322: 1345-9.

24 Knutson L, Ahrenstedt Ö, Odlind B, Hällgren R. The jejuna secretion of histamine is increased in active Crohn's disease. Gastroenterology 1990; 98: 849-54. 